\title{
Optimization of different culture conditions for enhanced laccase production and its purification from Tricholoma giganteum AGHP
}

Helina Patel and Akshaya Gupte*

\begin{abstract}
Background: In current times, enzyme-catalyzed reactions have gained importance for the development of new chemical processes. These require the production of large quantity of enzyme at low cost. Solid-state fermentation (SSF) is an efficient process because this bioprocess has a potential to convert agro-industrial residues into valuable compounds. Hence, the current study focuses on the optimization of process parameters for the higher production of laccase using a novel basidiomycete fungi Tricholoma giganteum AGHP under solid-state fermentation (SSF). Further, the purification of laccase using column chromatographic technique was performed.

Results: Various physico-chemical parameters were evaluated and maximum production obtained was $2.69 \times 10^{5}$ $\mathrm{U} / \mathrm{g}$ using wheat straw as a dry substrate. Optimum pH was found to be 5.0 and the temperature of $30^{\circ} \mathrm{C}$ with $0.3 \mathrm{mM}$ copper as an inducer. The enzyme was purified from the initial protein preparation by two-step column chromatography. A yield of $10.49 \%$ with 3.33-fold purification was obtained using Sephadex G-75 gel permeation chromatography. Further increase in purification (total) was found to be 10.80 -fold with a yield of $8.50 \%$ using DEAE Sephadex A-50 ion exchange column chromatography. The purified enzyme was identified as a monomeric protein with a molecular weight of $66 \mathrm{kDa}$ by sodium dodecyl sulfate-polyacrylamide gel electrophoresis (SDS-PAGE).

Conclusion: In view of the results obtained, we can conclude that the extracellular laccase production is governed by various cultural parameters such as $\mathrm{pH}$, temperature, and the composition of culture medium. "One-factor-ata-time" methodology was capable of establishing the optimum conditions that significantly increases the enzyme production several folds using lignocellulosic substrate. Therefore, laccase from T. giganteum AGHP has a potential in several industrial applications.
\end{abstract}

Keywords: Laccase, White rot fungi, Tricholoma giganteum, Solid-state fermentation, Inducers, Purification

\section{Background}

Laccase (E.C.1.10.3.2), an ubiquitous enzyme, is found in many higher basidiomycete fungi, plants, prokaryotes, and arthropods (Giardina et al. 2010). Laccases have also been isolated from insects, involved during sclerotization processing for epidermal cuticle synthesis (Sakurai and Kataoka 2007). In bacteria, laccases have functions

*Correspondence: akshaya_gupte@hotmail.com Department of Microbiology, Natubhai V. Patel College of Pure and Applied Sciences, Vallabh Vidyanagar, Gujarat 388 120, India like morphogenesis, pigment biosynthesis, and copper homeostasis (Strong and Claus 2011). Moreover, the fungal laccases are involved in sporulation, pigment production, fruiting body formation, and plant pathogenesis (Sadhasivam et al. 2008). Laccases are glycosylated polyphenol oxidase containing four copper ions per molecule and catalyze single-electron oxidation of a wide range of organic and inorganic substrates with a concomitant four-electron reduction of oxygen to water (Thurston 1994). The substrates include compounds like ortho- and 
para-diphenols, aromatic amines, methoxy-substituted phenols, and other non-phenolic substrates.

The white rot fungi are at present known to be the most efficient microorganisms capable of extensive lignin degradation. Laccase has emerged as an important enzyme as it has been successfully used in delignification (Sharma et al. 2005), dye degradation (Mendoza et al. 2011), bioremediation of toxic chemical wastes (Mayer and Staples 2002), and pretreatment of biomass for the production of biofuel (Placido and Capareda 2015). It has also been exploited for the development of biosensors to know the presence of xenobiotics (Duran et al. 2002).

The production of laccase by basidiomycetes using submerged fermentation has been reported extensively, in spite of the fact that these organisms grow in nature under solid-state conditions (El-Batal et al. 2015). However, the reports on the use of solid-state fermentation are scanty (Palmieri et al. 2003). SSF has emerged as a major thrust area for the production of enzymes and other economically potential products. This may be attributed to the high volumetric productivities, low capital costs, reduced energy requirement, and simple fermentation substrate/media (Kapoor et al. 2000).

The extracellular laccase production usually occurs during secondary metabolism of different fungi and is influenced by various cultivation conditions (RiveraHoyos et al. 2013). The availability of carbon, nitrogen source, and inducer concentration are the crucial factors affecting the enzyme production (Majeau et al. 2010). Thus, the present investigation was aimed to isolate a potent laccase producer, to optimize laccase production under SSF, its purification, and partial characterization.

\section{Methods}

\section{Chemicals}

2,2-Azino-bis (3-ethylbenzthiozoline-6-sulfonic acid) (ABTS), guaiacol, gallic acid, O-dianisidine, Sephadex G-75, and DEAE Sephadex A-50 were purchased from Sigma, St. Louis, MO, USA. Vanillin, pyrocatechol, and veratryl alcohol used were procured from Hi-Media Laboratories, Mumbai, India. Wheat straw, wheat bran, rice straw, and rice bran were collected locally and used as lignocellulosic substrates. All other chemicals used were of analytical grade and of highest purity available.

\section{Isolation and screening of new fungal isolate}

For isolation, different environmental samples like decayed wood, tree barks, and fruiting bodies were collected from the nearby vicinity of Anand and Vallabh Vidyanagar, Gujarat, India. Samples collected were suspended into the $0.01 \%(\mathrm{w} / \mathrm{v})$ mercuric chloride for 2-3 min for surface sterilization followed by washing with distilled water. For isolation, sterilized samples were then plated onto $2 \%(\mathrm{w} / \mathrm{v})$ malt extract agar (MEA) plates with streptomycin $(25 \mu \mathrm{g} / \mathrm{ml})$ and incubated at $30{ }^{\circ} \mathrm{C}$ for 8-10 days. Then, primary screening of the isolates was performed on $2 \%(\mathrm{w} / \mathrm{v})$ malt extract agar plate containing $0.01 \%(\mathrm{w} / \mathrm{v})$ ortho-dianisidine and guaiacol as a chromogenic substrate to check the presence of polyphenol oxidase activity (Ravikumar et al. 2012).

\section{Culture conditions for laccase production under SSF}

The moistening medium for the solid-state fermentation was prepared using medium described by Asther et al. (1988). Five grams of lignocellulosic substrate (wheat straw, wheat bran, rice straw, rice bran) was moistened with $20 \mathrm{ml}$ of medium containing $(\mathrm{g} / \mathrm{l})$ Tween 80 0.1, $\mathrm{KH}_{2} \mathrm{PO}_{4} 0.2, \mathrm{CaCl}_{2} \cdot 2 \mathrm{H}_{2} \mathrm{O}$ 0.0132, $\mathrm{MgSO}_{4} \cdot 7 \mathrm{H}_{2} \mathrm{O} \quad 0.05$, $\mathrm{FeC}_{6} \mathrm{H}_{5} \mathrm{O}_{7} \cdot \mathrm{NH}_{4} \mathrm{OH}$ (ammonium ferric citrate) 0.085, $\mathrm{ZnSO}_{4} \cdot 7 \mathrm{H}_{2} \mathrm{O} 0.0462, \mathrm{MnSO}_{4} \cdot 7 \mathrm{H}_{2} \mathrm{O} 0.035, \mathrm{CoCl}_{2} \cdot 6 \mathrm{H}_{2} \mathrm{O}$ 0.007, $\mathrm{CuSO}_{4} \cdot 5 \mathrm{H}_{2} \mathrm{O}$ 0.007, L-asparagine 1.0, $\mathrm{NH}_{4} \mathrm{NO}_{3}$ 0.5 , thiamine- $\mathrm{HCl} 0.0025$, yeast extract 0.2 , and glucose 10. Each flask was inoculated with five agar plugs $(9 \mathrm{~mm}$ diameter) of actively growing mycelia from potato dextrose agar plates and incubated at $30^{\circ} \mathrm{C}$ for 16 days under static condition. After 16 days of incubation, enzyme was extracted by adding $20 \mathrm{ml}$ of $100 \mathrm{mM}$ sodium acetate buffer ( $\mathrm{pH}$ 5.0) and the contents were transferred to a muslin cloth and filtered. The extract obtained was then centrifuged at $8000 \times g$ for $20 \mathrm{~min}$ at $4{ }^{\circ} \mathrm{C}$ and the supernatant obtained was analyzed for laccase activity using the method of Niku-Paavola et al. (1990).

\section{Effect of different lignocellulosic substrates}

The fungal isolate Tricholoma giganteum AGHP was grown in 250-ml Erlenmeyer flasks containing $5 \mathrm{~g}$ each of different lignocellulosic substrates (wheat straw, wheat bran, rice straw, rice bran) of $0.5 \mathrm{~mm}$ particle size and moistened with Asther medium. The fermentation was carried out at a moisture content of 1:4 and an initial $\mathrm{pH}$ 5.0. Enzyme was extracted on the 16th day of incubation at $30^{\circ} \mathrm{C}$.

\section{Effect of moisture content}

The influence of moisture content on the laccase production was evaluated using different combinations of solid substrate-to-moistening agent ratio $(\mathrm{w} / \mathrm{v})$ of 1:3, 1:4, 1:5, $1: 6,1: 6.5,1: 7,1: 7.5,1: 8,1: 8.5,1: 9,1: 9.5$, and 1:10 using wheat straw as a solid substrate. The initial $\mathrm{pH}$ of the medium was 5.0 and enzyme was extracted on the 16th day of incubation at $30^{\circ} \mathrm{C}$.

\section{Effect of $\mathrm{pH}$ and temperature}

To evaluate the effect of initial $\mathrm{pH}$ of the medium on laccase production, the $\mathrm{pH}$ of Asther medium was varied in the range of 3.0-10.0. The fermentation was carried out 
at a moisture content of 1:4 and enzyme was extracted on the 16 th day of incubation at $30^{\circ} \mathrm{C}$.

The effect of temperature on laccase production by $T$. giganteum AGHP was studied by incubating the flasks at $10,15,20,30,35$, and $45^{\circ} \mathrm{C}$. The fermentation was carried out for 16 days with 1:4 moisture content and initial medium $\mathrm{pH}$ 5.0.

\section{Effect of co-substrates}

Production of laccase was studied by supplementing different carbon sources such as glucose, fructose, mannose, mannitol, xylose, sucrose, maltose, and lactose $(1 \% \mathrm{w} / \mathrm{v})$ into Asther medium. The control flask was devoid of any co-substrate. The fermentation was carried out at $30{ }^{\circ} \mathrm{C}$ for 16 days, at 1:4 moisture content and initial medium pH 5.0.

\section{Effect of nitrogen source}

To optimize the nitrogen source, various organic (yeast extract, asparagine, thiamine- $\mathrm{HCl}$ ) and inorganic (ammonium nitrate, ammonium ferric citrate, ammonium sulfate) nitrogen sources present into Asther medium were added independently into the medium at a final concentration of $10 \mathrm{mM}$. The control flask contained a combination of all nitrogen sources present into Asther medium. The fermentation was carried out at 1:4 moisture content and initial medium pH 5.0 using glucose as a co-substrate. The enzyme was extracted on the 16 th day of incubation at $30^{\circ} \mathrm{C}$.

\section{Effect of different surfactants}

To evaluate the effect of different surfactants on laccase production, five different surfactants (Tween 20, Tween 40, Tween 60, Tween 80, and Triton X-100) at four different concentrations $(0.05,0.1,0.15$, and $0.2 \mathrm{~g} / \mathrm{l})$ were incorporated into the Asther medium. The control flask was devoid of any surfactant. The fermentation was carried out for 16 days at $30{ }^{\circ} \mathrm{C}$, with $1: 4$ moisture content, initial medium pH 5.0, glucose as a co-substrate, and all organic and inorganic nitrogen sources present into the Asther medium as a nitrogen source.

\section{Effect of different inducers and copper ion concentration}

To determine the effect of inducers on laccase production, seven different inducers (copper sulfate, $o$-dianisidine, guaiacol, vanillin, catechol, gallic acid, and veratryl alcohol) (1 mM) were incorporated independently into Asther medium. The control flask was devoid of any inducer. Further effect of copper ion concentration was evaluated by incorporating different concentrations of copper ion (0.05-3 mM) into the Asther medium. The fermentation was carried out at $30{ }^{\circ} \mathrm{C}$ for 16 days, with
1:4 moisture content, medium $\mathrm{pH} 5.0$, glucose as a cosubstrate, and organic and inorganic nitrogen sources present into the Asther medium as a nitrogen source incorporated with $0.15 \mathrm{~g} / \mathrm{l}$ Tween 80 as a surfactant.

\section{Time course study of laccase production}

Wheat straw (5 g) was moistened with $20 \mathrm{ml}$ of unoptimized and optimized Asther medium in 250-ml flasks, inoculated with five agar disks, and incubated at $30{ }^{\circ} \mathrm{C}$ for 20 days. The content of the flasks was harvested after every $24 \mathrm{~h}$ and assayed.

\section{Optimized culture conditions for laccase production}

The optimized medium for laccase production contains (g/l) Tween $800.15, \mathrm{KH}_{2} \mathrm{PO}_{4} 0.2, \mathrm{CaCl}_{2} \cdot 2 \mathrm{H}_{2} \mathrm{O}$ 0.0132, $\mathrm{MgSO}_{4} \cdot 7 \mathrm{H}_{2} \mathrm{O} 0.05, \mathrm{FeC}_{6} \mathrm{H}_{5} \mathrm{O}_{7} \cdot \mathrm{NH}_{4} \mathrm{OH}$ (ammonium ferric citrate) $0.085, \mathrm{ZnSO}_{4} \cdot 7 \mathrm{H}_{2} \mathrm{O} \quad 0.0462, \mathrm{MnSO}_{4} \cdot 7 \mathrm{H}_{2} \mathrm{O}$ $0.035, \mathrm{CoCl}_{2} \cdot 6 \mathrm{H}_{2} \mathrm{O} 0.007, \mathrm{~L}$-asparagine 1.0, $\mathrm{NH}_{4} \mathrm{NO}_{3} 0.5$, thiamine- $\mathrm{HCl} 0.0025$, yeast extract 0.2 , and glucose 10 , supplemented with $0.3 \mathrm{mM}$ copper sulfate as an inducer with an initial medium $\mathrm{pH}$ of 5.0 and incubation temperature $30{ }^{\circ} \mathrm{C}$ for 16 days using wheat straw as a solid substrate.

\section{Estimation of fungal biomass}

The estimation of fungal biomass was carried out by the method described by Couto et al. (2009). To determine the fungal biomass, $25 \%$ of the solid substrates (SS) were labeled using small holes in different distributions for possible monitoring during the cultivation process. At different time intervals, all solid substrates were dried and weighed to determine the original weight $\left(W_{0}\right)$. After cultivation, the complex support-mycelium was collected and dried until constant weight $\left(W_{\mathrm{c}}\right)$. The labeled solid substrates without fungus were separated and weighed for calculating the amount of degraded support (Ds). The amount of degraded support (Ds) corresponded to mean difference between original and final dry weight $(\mathrm{g})$ of labeled SS without fungus was determined from

$$
D \mathrm{~s}=\frac{1}{N} \sum_{n=1}^{N}\left(W_{0}-W_{\mathrm{f}}\right) n,
$$

where $W_{0}$ and $W_{\mathrm{f}}$ are the original and final dry weights of each labeled SS $(n)$, respectively, and $N$ is the total labeled $\mathrm{SS}$ used in the test. The ratio between DS and $\mathrm{W}_{0}$ of the labeled SS without fungus corresponded to the mean amount of degraded SS $\left(\mathrm{RD}_{\mathrm{S}}\right)$ as indicated in the following equation:

$$
\mathrm{RDs}=\frac{D s}{\sum_{n=1}^{N}\left(W_{0}\right) n} .
$$


The fungal biomass (FB) was calculated as the difference between $W c, W_{0}$ plus RDs multiplied by $W_{0}$ as given in the following equation:

$$
F B=W_{\mathrm{c}}-W_{0}\left(1-\mathrm{RD}_{\mathrm{s}}\right) .
$$

\section{Enzyme assay}

Laccase (E.C.1.10.3.2) activity was determined using the method of Niku-Paavola et al. (1990). The increase in absorbance related to the oxidation of 2, 2-azinobis-3-ethylbenzthiozoline-6- sulfonic acid (ABTS, $\varepsilon=36,000 \mathrm{~cm}^{-1} \mathrm{M}^{-1}$ ) was measured spectrophotometrically at $420 \mathrm{~nm}$ for $3 \mathrm{~min}$. The reaction mixture contained $100 \mu \mathrm{l}$ of $50 \mathrm{mM}$ ABTS, $800 \mu \mathrm{l}$ of $100 \mathrm{mM}$ sodium acetate buffer (pH 5.0), and $100 \mu \mathrm{l}$ of enzyme extract. One unit of enzyme activity $(\mathrm{U})$ was defined as the amount of enzyme that oxidized $1 \mu \mathrm{M}$ of substrate/min under the standard reaction condition.

\section{Protein determination}

Total protein was estimated quantitatively by Lowry's method (1951) with bovine serum albumin as standard.

\section{Purification of laccase Ammonium sulfate precipitation and dialysis}

The production of laccase using T. giganteum AGHP was carried out using wheat straw as a solid support under optimized culture conditions. At the end of the fermentation cycle, the enzyme was extracted by adding $100 \mathrm{mM}$ sodium acetate buffer ( $\mathrm{pH}$ 5.0) and the contents were transferred to a muslin cloth and filtered. The extract obtained was then centrifuged at $8000 \times g$ for $20 \mathrm{~min}$ at $4{ }^{\circ} \mathrm{C}$ and the supernatant obtained was subjected to ammonium sulfate saturation in the range of $0-80 \%$ $(\mathrm{w} / \mathrm{v})$ at low temperature. The saturated solution was left overnight at $4{ }^{\circ} \mathrm{C}$, the precipitated protein was sedimented by centrifuging at $10,000 \times g$ for $10 \mathrm{~min}$ at $4{ }^{\circ} \mathrm{C}$, and the pellet was resuspended in minimum volume of $100 \mathrm{mM}$ sodium acetate buffer ( $\mathrm{pH}$ 5.0). The concentrated sample with maximum laccase activity was dialyzed overnight against $100 \mathrm{mM}$ sodium acetate buffer (pH 5.0).

\section{Purification of laccase by column chromatography}

The dialyzed sample was loaded onto the Sephadex G-75 gel permeation column $(1.5 \times 30 \mathrm{~cm})$ for purification. The column was equilibrated and eluted with $100 \mathrm{mM}$ sodium acetate buffer ( $\mathrm{pH} 5.0$ ) at a flow rate of $0.2 \mathrm{ml} /$ $\mathrm{min}$. The laccase activity and protein content of all the fractions were determined. The fraction with maximum laccase activity was then re-applied to the DEAE Sephadex A-50 ion exchange column $(1.5 \times 30 \mathrm{~cm})$ with bed volume $25 \mathrm{ml}$ previously equilibrated with $100 \mathrm{mM}$ sodium acetate buffer ( $\mathrm{pH}$ 5.0). A continuous linear gradient of $\mathrm{NaCl}(0.1-1 \mathrm{M})$ was applied and the fractions were collected at a flow rate of $0.2 \mathrm{ml} / \mathrm{min}$. The laccase activity and the total protein content of all the fractions were determined. The fractions containing high laccase activity were pooled and stored at $4{ }^{\circ} \mathrm{C}$ for further use.

\section{Molecular weight determination}

Sodium dodecyl sulfate-polyacrylamide gel electrophoresis (SDS-PAGE) and native-PAGE (10\% resolving gel and $5 \%$ stacking gel) were performed to determine the purity of the protein and its molecular weight according to the modified method of Laemmli (1970). In SDS-PAGE, the protein bands were visualized by silver nitrate staining method and the approximate molecular weight was determined by comparison with the standard molecular weight markers [Myosin, rabbit muscle (205 kDa), phosphorylase b $(97.4 \mathrm{kDa})$, bovine serum albumin $(66.0 \mathrm{kDa})$, ovalbu$\min (43.0 \mathrm{kDa})$, and carbonic anhydrase $(29.0 \mathrm{kDa})]$. After native-PAGE, the gel was subjected to activity staining for laccase. The gel was allowed to stand in $100 \mathrm{mM}$ of sodium acetate buffer (pH 5.0) with $10 \mathrm{mM}$ of ABTS for 20-30 min. The bands of protein associated with laccase activity were indicated by the development of green color.

\section{Results and discussion}

\section{Isolation and screening of new fungal isolate}

Eleven different fungal strains were isolated and, out of them, four isolates showed a positive phenol oxidase activity when subjected to primary screening with $0.01 \%(\mathrm{w} / \mathrm{v})$ different chromogenic substrates like guaiacol, gallic acid, and ortho-dianisidine supplemented to malt extract agar plate. Isolates obtained were further subjected for the quantitative detection of laccase under solid-state fermentation. Out of the four isolates, fungal isolate designated as AGHP showed the highest laccase production and was selected for further studies. The molecular identification of fungal isolate AGHP was done based on its ITS4 (5'-TCCTCCGCTTATTG ATATGC-3') and ITS5 (5'-GGAAGTAAAAGTCGT AACAAGG-3') (White et al. 1990) gene sequencing carried out by Agharkar Research Institute, Pune, India. Percentage homology with other ITS sequences in the NCBI database showed that the sequence of this DNA fragments has $100 \%$ identity with $T$. giganteum isolate CBE (Coimbatore) (Prakasam et al. 2011). On the basis of sequence homology, the isolate AGHP was identified as T. giganteum AGHP (Accession no. KT154749).

\section{Effect of different lignocellulosic substrates}

The selection of lignocellulosic substrate under solidstate fermentation is very important for the efficient and cost-effective production of the ligninolytic enzymes. Different lignocellulosic substrates like wheat straw, 
wheat bran, rice straw, and rice bran were screened for the production of laccase. All the lignocellulosic substrates used supported the growth of fungi with good laccase production. Among all substrates, wheat straw was found to be the most suitable for laccase production $\left(8.98 \times 10^{4} \mathrm{U} / \mathrm{g}\right.$ of dry substrate) (Fig. 1a) using T. giganteum AGHP with complete colonization of substrate on the 16th day of incubation; this is because of the high cellulosic, hemi-cellulosic, protein, and lignin content present in the wheat straw making it a balanced substrate for microorganisms (Khan and Mubeen 2012). Maximum biomass was obtained on the 16 and 20th day of incubation using wheat straw (5.59 $\mathrm{g} \%$ ) and rice straw (2.1 g \%), respectively, and on the 18th day of incubation using wheat bran (5.47 g \%) and rice bran (0.92 g \%) (Fig. 1b). The results showed a linear correlation between biomass and laccase production. The results obtained are in agreement with those of Patel et al. (2009) who reported wheat straw as a best substrate for laccase production by Pleurotus ostreatus HP-1 under SSF. Arora et al. (2000) reported up to 59 -fold increase in enzyme production by

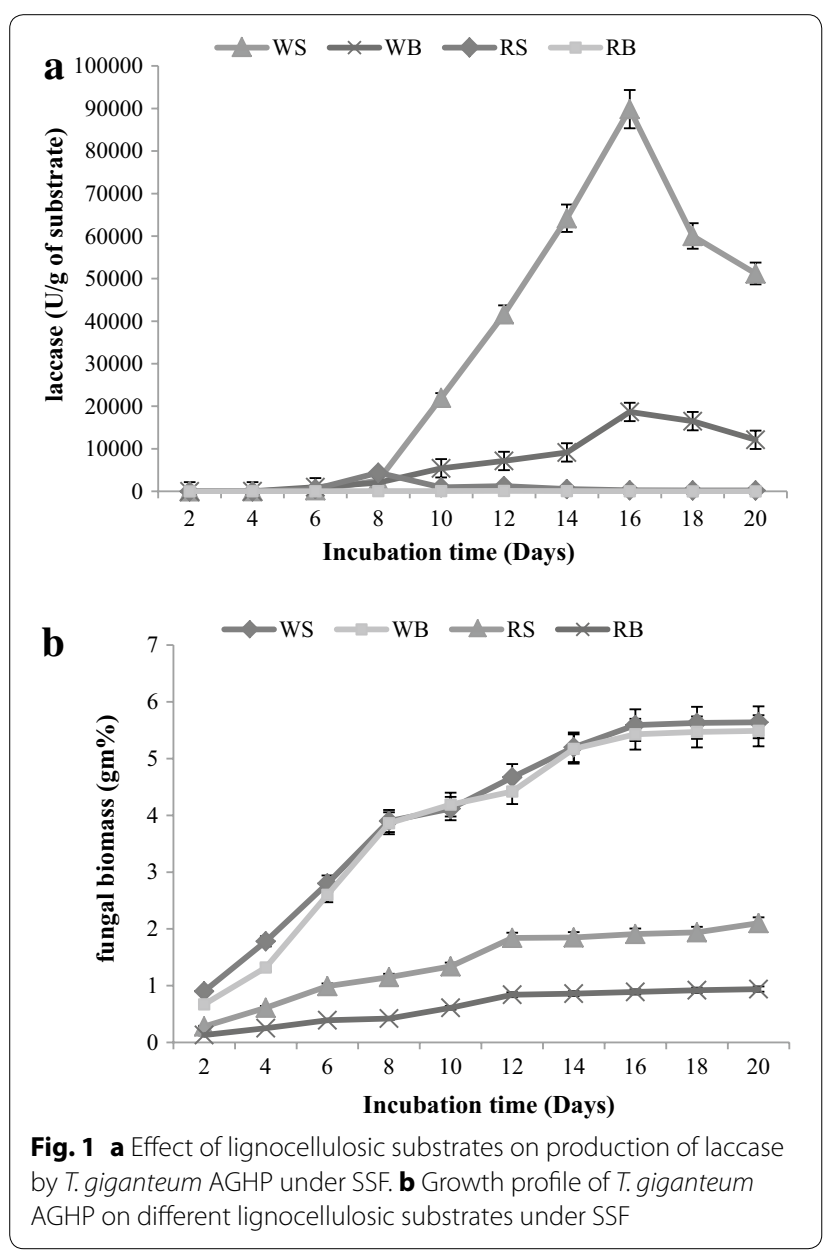

supplementation of wheat straw to the mineral salt broth. El-Batal et al. (2015) reported maximum production of laccase with Pleurotus ostreatus under SSF using wheat bran as a solid substrate. Higher laccase production with a novel lignocellulosic biomass tamarind shell has been reported by Manavalan et al. (2013). However, the results obtained prove the efficacy of wheat straw for substantial enzyme production.

\section{Effect of moisture content}

Moisture ratio is a key factor in SSF that influences the laccase production. Laccase production was evaluated using different combinations of solid substrate-to-moistening medium ratio of 1:3, 1:4, 1:5, 1:6, 1:6.5, 1:7, 1:7.5, $1: 8,1: 8.5,1: 9,1: 9.5$, and 1:10 (w/v). Moisture content of 1:4 was found to be most suitable for the laccase production and the maximum production obtained was $1.32 \times 10^{5} \mathrm{U} / \mathrm{g}$ of dry substrate (Fig. 2). However, any further increase in moisture ratio decreases the laccase production. This may be attributed to particle agglomeration, limitation in gas transfer, and competition from the bacteria (Xin and Geng 2011). In SSF processes, moisture level varies between 30 and $85 \%$. For bacteria, the moisture of the solid substrate must be higher than $70 \%$, whereas, for filamentous fungi, it is between $20-70 \%$ (Chundakkadu 2005).

\section{Effect of $\mathrm{pH}$ and temperature}

The $\mathrm{pH}$ of the culture medium was varied from 3.0 to 10.0. However, the optimal activity is mainly obtained in the $\mathrm{pH}$ range of 3.0-5.0. In the present study, the maximal laccase production $\left(1.27 \times 10^{5} \mathrm{U} / \mathrm{g}\right.$ of dry substrate $)$ (Fig. 3a) was obtained at $\mathrm{pH}$ 5.0. Further rise in $\mathrm{pH}$ showed no increase in the production of enzyme. This may be attributed to the poor mycelial growth at an elevated $\mathrm{pH}$ which may restrict the laccase production. Similar result has been reported by Ravikumar et al. (2012) with maximum enzyme production at $\mathrm{pH}$ 5.0. Chhaya

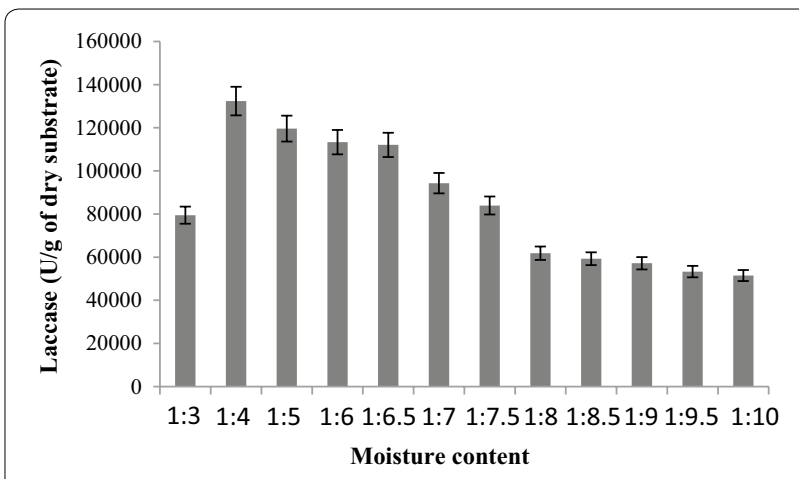

Fig. 2 Effect of moisture content on laccase production using wheat straw as a solid substrate and Asther's medium as a moistening agent 

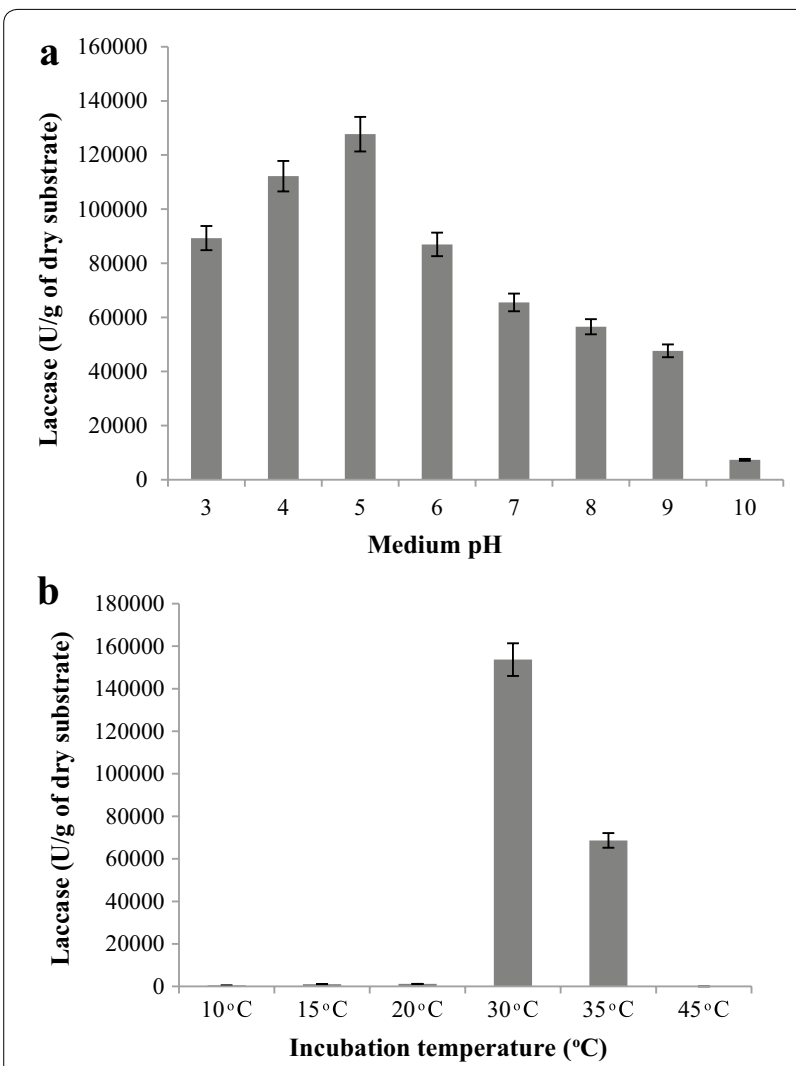

Fig. 3 a Influence of initial pH of Asther's medium on laccase production using wheat straw and 1:4 moisture content on the 16th day of fermentation. b Production of laccase at different incubation temperatures using wheat straw, 1:4 moisture content, and initial medium $\mathrm{pH} 5.0$ on the 16 th day of fermentation

and Gupte (2013) also reported maximum enzyme production at pH 5.0 using one-factor-at-a-time methodology under solid-state fermentation.

Incubation temperature is an important factor affecting the fermentation process in SSF because both growth of fungi and production of an enzyme are sensitive to temperature. To check the effect of temperature on laccase production, T. giganteum AGHP was grown in the temperature range of $10-45{ }^{\circ} \mathrm{C}$. The maximum production of laccase $\left(1.53 \times 10^{5} \mathrm{U} / \mathrm{g}\right.$ of dry substrate) (Fig. $\left.3 \mathrm{~b}\right)$ was obtained at $30{ }^{\circ} \mathrm{C}$. Higher temperatures lead to adverse effect on the metabolic activity of the microorganisms, thereby leading to the denaturation of the key enzymes. However, lower temperature of 10 and $20^{\circ} \mathrm{C}$ did not support the growth of fungi, thus leading to lower enzyme production. Xin and Geng (2011) have also reported that the lower temperature retards the metabolic rate of Trametes versicolor leading to the decrease in laccase production. Many researchers have reported an optimum temperature between 25 and $30{ }^{\circ} \mathrm{C}$ for laccase production using various white rot fungi (Ravikumar et al. 2012; Chhaya and Gupte 2013; Elsayed et al. 2012).

\section{Effect of co-substrates}

Selection of an appropriate carbon source is important in growth and metabolism of fungi, hence affecting the enzyme production. In addition to carbon and energy source, co-substrates also provide necessary inducing compounds for the organisms that are responsible for increasing the productivity of the fermentation process. Examining the effect of co-substrates on laccase production showed that maximum production was obtained using glucose $\left(1.59 \times 10^{5} \mathrm{U} / \mathrm{g}\right.$ of dry substrate) (Fig. 4) followed by sucrose $\left(5.31 \times 10^{4} \mathrm{U} / \mathrm{g}\right.$ of dry substrate), xylose $\left(4.98 \times 10^{4} \mathrm{U} / \mathrm{g}\right.$ of dry substrate), and fructose $\left(4.38 \times 10^{4} \mathrm{U} / \mathrm{g}\right.$ of dry substrate). The control flask without co-substrate showed comparatively low enzyme production $\left(3.95 \times 10^{4} \mathrm{U} / \mathrm{g}\right.$ of dry substrate). Thus, the addition of co-substrate has a noticeable effect on laccase production. Glucose has been reported as an effective co-substrate for laccase production using Ganoderma lucidum by Ding et al. (2012). However, Johnsy and Kaviyarasan (2011) reported fructose as the best co-substrate for laccase production by Lentinus kauffmanii.

\section{Effect of nitrogen source}

The effect of nitrogen source on laccase production by different organisms appears to be greatly controversial (Collins and Dobson 1997). Ligninolytic enzyme production has been reported in both nitrogen-sufficient and nitrogen-deficient media using different organisms. The results of the present study indicated that laccase production was higher $\left(1.51 \times 10^{5} \mathrm{U} / \mathrm{g}\right.$ of dry substrate) (Fig. 5) in the control flask having all the organic and inorganic

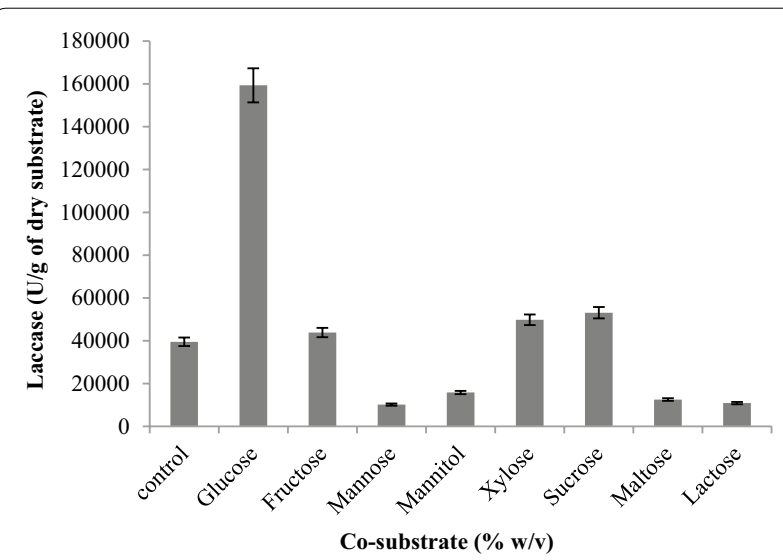

Fig. 4 Effect of co-substrates on laccase production using Asther's medium with varying co-substrate $(1 \% \mathrm{w} / \mathrm{v})$, initial medium $\mathrm{pH}$ 5.0, and temperature $30^{\circ} \mathrm{C}$ on the 16 th day of fermentation 


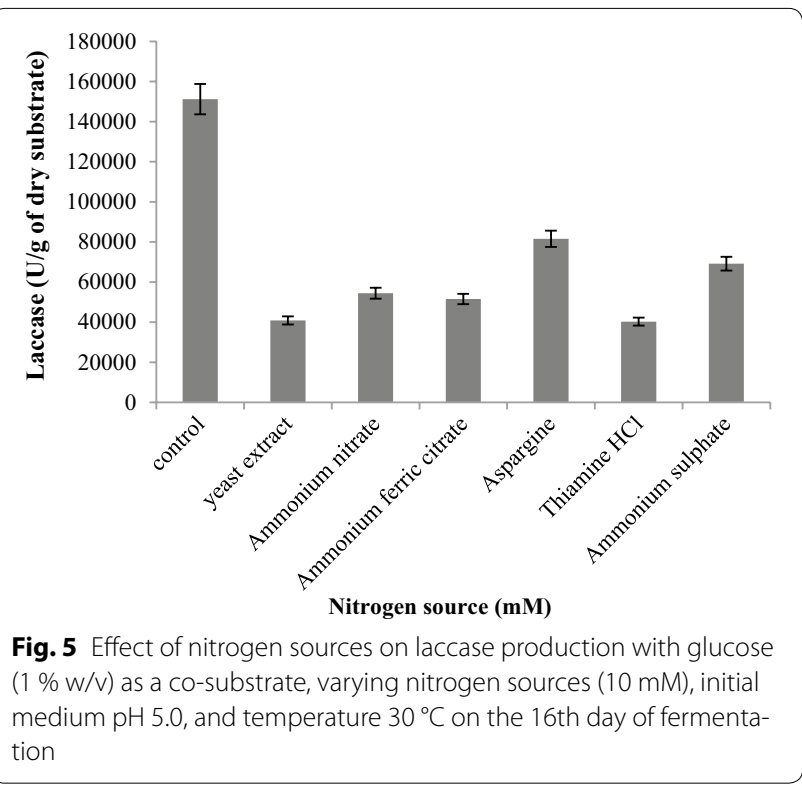

sources of the Asther medium except ammonium sulfate. However, the use of different organic and inorganic nitrogen sources of the Asther medium as a sole nitrogen source independently did support the growth of the fungi, but the enzyme production was low, while the presence of both organic and inorganic nitrogen sources together as in Asther's medium favored the higher laccase production, indicating the suitability of combined organic and inorganic nitrogen source for the laccase production by T. giganteum AGHP. Thus, the replacement of the known nitrogen sources from the Asther medium failed to enhance the laccase production. Therefore, Asther medium containing all nitrogen sources was used in our further studies. Dong et al. (2005) have reported improved laccase production using tryptone and peptone. Revankar and Lele (2006) reported yeast extract as a suitable nitrogen source for laccase production.

\section{Effect of different surfactants}

Addition of surface-active agents provides higher permeability of oxygen and extracellular enzyme transport through the cell membranes of fungi (El-Batal et al. 2015). Thus, the addition of surfactants to the medium not only helps in secretion of the extracellular enzyme, but can increase the bioavailability of less-soluble substrates for the fungi and also stimulate the growth of the fungi. The present study demonstrates the effect of different surfactants like Tween 20, Tween 40, Tween 80, SDS, and Triton X-100 on laccase production by adding surfactants in the Asther medium in a range of $0.05-0.2$ $(\mathrm{g} / \mathrm{l})$. Enhanced laccase production $\left(1.65 \times 10^{5} \mathrm{U} / \mathrm{g}\right.$ of dry substrate) (Fig. 6) was obtained using $0.15 \mathrm{~g} / \mathrm{l}$ Tween

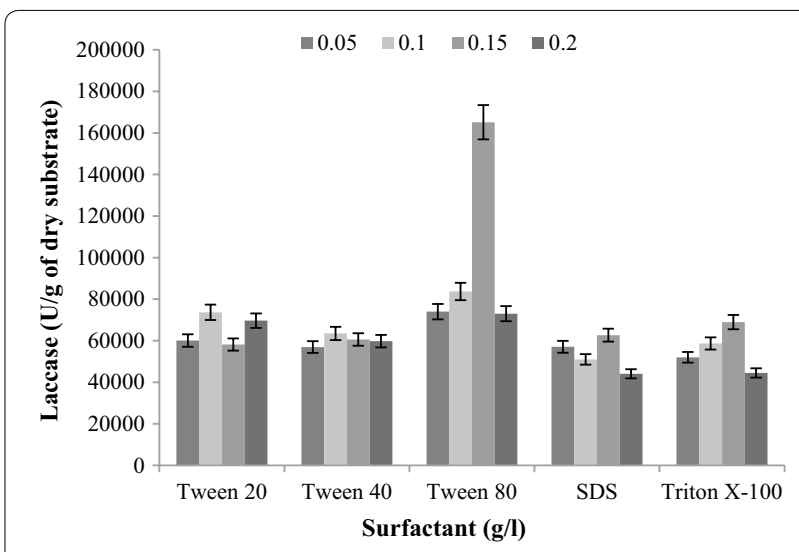

Fig. 6 Effect of ionic and non-ionic surfactants on laccase production using optimized Asther's medium with initial medium $\mathrm{pH} 5.0$ and temperature $30^{\circ} \mathrm{C}$ on the 16 th day of fermentation. Control flask was devoid of any surfactant

80 as a surfactant with 1.97 -fold increase in production as compared to that of the Asther medium having $0.1 \mathrm{~g} / \mathrm{l}$ Tween 80 . However, in case of Pleurotus ostreatus ARC280 the maximum laccase production was attained using $0.1 \%(\mathrm{v} / \mathrm{v})$ Tween 80 (Elsayed et al. 2012). Lestan et al. (1994) also reported the increase in yield of ligninolytic enzymes after the addition of surfactants Tween 20 and Tween 80 to the medium.

\section{Effect of different inducers and copper ion concentration}

Supplementation of an appropriate inducer can greatly enhance the laccase production. Different compounds such as phenolic and non-phenolic substrates can act as inducers. The most common and effective inducers used for laccase production are copper, 2,5 xylidine, guaiacol, ethanol, etc. The production of laccase from T. giganteum was evaluated in the presence of seven different inducer compounds (copper sulfate, $o$-dianisidine, guaiacol, vanillin, pyrocatechol, gallic acid, and veratryl alcohol). From Fig. 7, it is observed that all the inducers are capable of enhancing the production of laccase. Among all, copper sulfate was found to be the most promising inducer for laccase production $\left(1.44 \times 10^{5} \mathrm{U} / \mathrm{g}\right.$ of dry substrate) (Fig. 7) followed by veratryl alcohol $\left(1.38 \times 10^{5} \mathrm{U} / \mathrm{g}\right.$ of dry substrate) and vanillin $\left(1.35 \times 10^{5} \mathrm{U} / \mathrm{g}\right.$ of dry substrate). Furthermore, various concentrations of copper in the range of $0.05-3 \mathrm{mM}$ were studied. Maximum production of laccase $\left(2.90 \times 10^{5} \mathrm{U} / \mathrm{g}\right.$ of dry substrate) (Table 1$)$ was obtained at $0.3 \mathrm{mM}$ copper concentration with a yield index of 2.15. Any further increase in the copper concentration beyond $0.3 \mathrm{mM}$ leads to the decrease in enzyme production. This may be because higher concentration of copper is an inhibitor of fungal growth, which is a key component in many fungicides (Revankar and Lele 2006). 


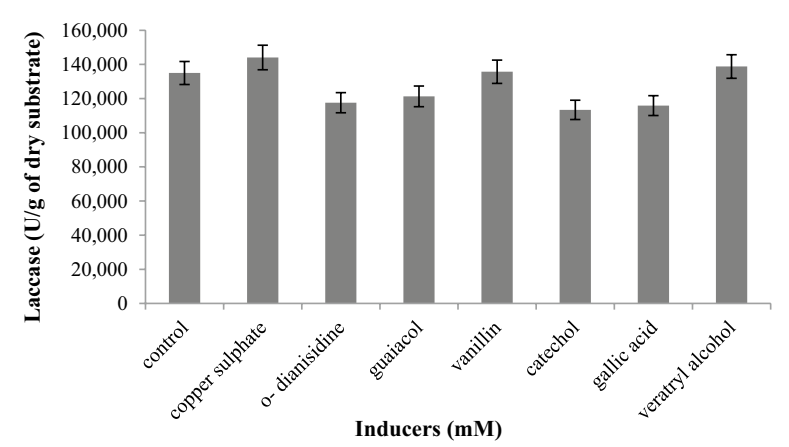

Fig. 7 Effect of different aromatic inducers and copper sulfate on laccase production using optimized Asther's medium with initial medium pH 5.0 and temperature $30^{\circ} \mathrm{C}$ on the 16th day of fermentation. Control flask was devoid of any inducer

Table 1 Effect of copper ion concentration on laccase production

\begin{tabular}{lll}
\hline Copper ion $(\mathbf{m M})$ & Laccase $\mathbf{( U / g}$ of dry substrate) & Yield index \\
\hline Control & $135100 \pm 2049.93$ & 1 \\
0.05 & $39900 \pm 857.64$ & 0.29 \\
0.1 & $71883 \pm 1714.25$ & 0.53 \\
0.2 & $239433 \pm 1755.90$ & 1.77 \\
0.3 & $290777 \pm 2225.15$ & 2.15 \\
0.4 & $169551 \pm 2125.01$ & 1.25 \\
0.5 & $158412 \pm 2154.05$ & 1.17 \\
1 & $144569 \pm 2382.51$ & 1.07 \\
1.5 & $121562 \pm 1952.23$ & 0.9 \\
2 & $118778 \pm 1710.30$ & 0.88 \\
2.5 & $117414 \pm 2563.78$ & 0.87 \\
3 & $116111 \pm 2339.71$ & 0.86 \\
\hline
\end{tabular}

Values are the average of three experiments and standard deviations are less than $5 \%$ of the mean

Xin and Geng (2011) also reported veratryl alcohol and copper sulfate as efficient inducers for laccase production by Trametes versicolor. However, the addition of 1-3 mM $\mathrm{Cu}^{+2}$ can significantly increase the laccase production up to two-fold by Ganoderma lucidum 447 (Songulashvili et al. 2011). Moreover, Manavalan et al. (2013) and Mann et al. (2015) reported that the addition of 0.75 and $0.4 \mathrm{mM}$ copper is significant to induce laccase production in Cerrena consors and Ganoderma lucidum, respectively.

\section{Time course study of laccase production}

Time course study of laccase production by T. giganteum AGHP was conducted before and after the medium optimization under SSF. Laccase production increased 3.02fold compared to that of unoptimized medium with the maximum production of $2.69 \times 10^{5} \mathrm{U} / \mathrm{g}$ of dry substrate and $6.02 \mathrm{~g} \%$ of fungal biomass (Fig. 8) on the 16th day of

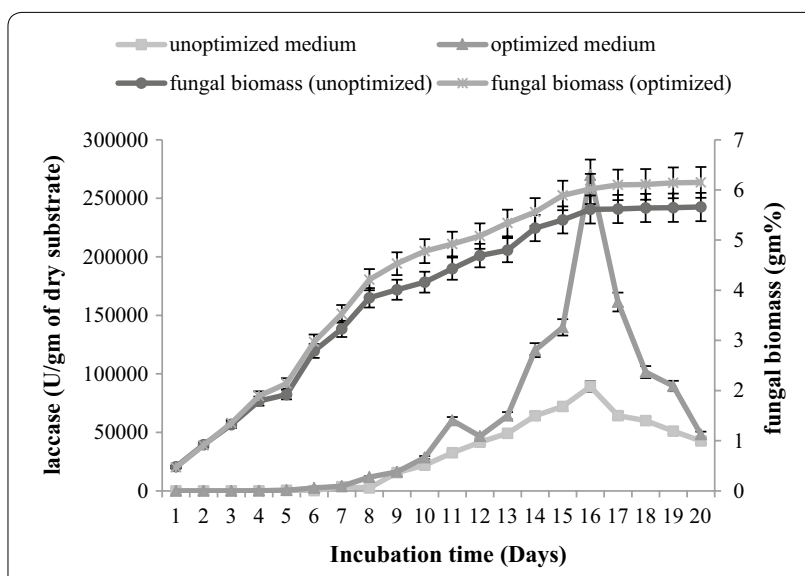

Fig. 8 Time course study of laccase and biomass production by $T$. giganteum AGHP using optimized and unoptimized Asther's medium

incubation. Shankar and Shikha (2012) reported 2.49-fold higher laccase production under optimized condition by Peniophora $s p$. The time course study for laccase production indicated that maximum production of enzyme and fungal biomass was obtained on the 16th day of fermentation. Similar results are obtained in case of Phlebia floridensis with maximum laccase and biomass production on the 8th day of incubation by Arora et al. (2000).

\section{Purification of laccase}

The extracellular laccase obtained from T. giganteum AGHP was purified to homogeneity using ammonium sulfate precipitation followed by two-step column chromatographic technique. The results of laccase purification at different steps are summarized in Table 2. The crude filtrate, subjected to ammonium sulfate precipitation and dialysis, showed specific activity of $4.95 \times 10^{4} \mathrm{U} /$ $\mathrm{mg}$ with 1.53 -fold purification. In the next step of purification by Sephadex G-75 gel permeation chromatography, four active fractions having laccase activity were pooled. The specific activity of $1.07 \times 10^{5} \mathrm{U} / \mathrm{mg}$ and $10.49 \%$ yield were achieved with 3.33-fold purification. The enzyme was further purified by DEAE Sephadex A-50 ion exchange column chromatography with a specific activity of $3.49 \times 10^{5} \mathrm{U} / \mathrm{mg}$ and a final yield of $8.50 \%$ with 10.80 -fold purification. The purification of laccase obtained in the present study is comparable with Chaurasia et al. (2014) who reported purification (10.42fold) with $12.57 \%$ yield of laccase from Trametes hirsuta MTCC-1171 using DEAE cellulose column chromatography. However, Yan et al. (2014) reported 1.37- and 4.07 -fold purification with 5.78 and $11.64 \%$ yield of laccase from T. trogii $\mathrm{S} 0301$ using anionic exchange chromatography followed by Sephadex G-75 chromatography, respectively. 
Table 2 Purification of laccase from T. giganteum AGHP

\begin{tabular}{|c|c|c|c|c|c|}
\hline Purification step & Total activity (U) & Total protein (mg) & Specific activity (U/mg) & Yield (\%) & Purification fold \\
\hline Crude filtrate & $8,222,200$ & 254 & $32,370.86$ & 100 & 1 \\
\hline Ammonium sulfate precipitation & $7,660,050$ & 181.5 & $42,204.13$ & 93.16 & 1.30 \\
\hline Dialyzed & $2,260,830$ & 45.6 & $49,579.60$ & 27.49 & 1.53 \\
\hline Gel permeation chromatography & 863,300 & 8.00 & $1,07,912.50$ & 10.49 & 3.33 \\
\hline Ion exchange chromatography & 699,225 & 2.00 & $3,49,612.50$ & 8.50 & 10.80 \\
\hline
\end{tabular}

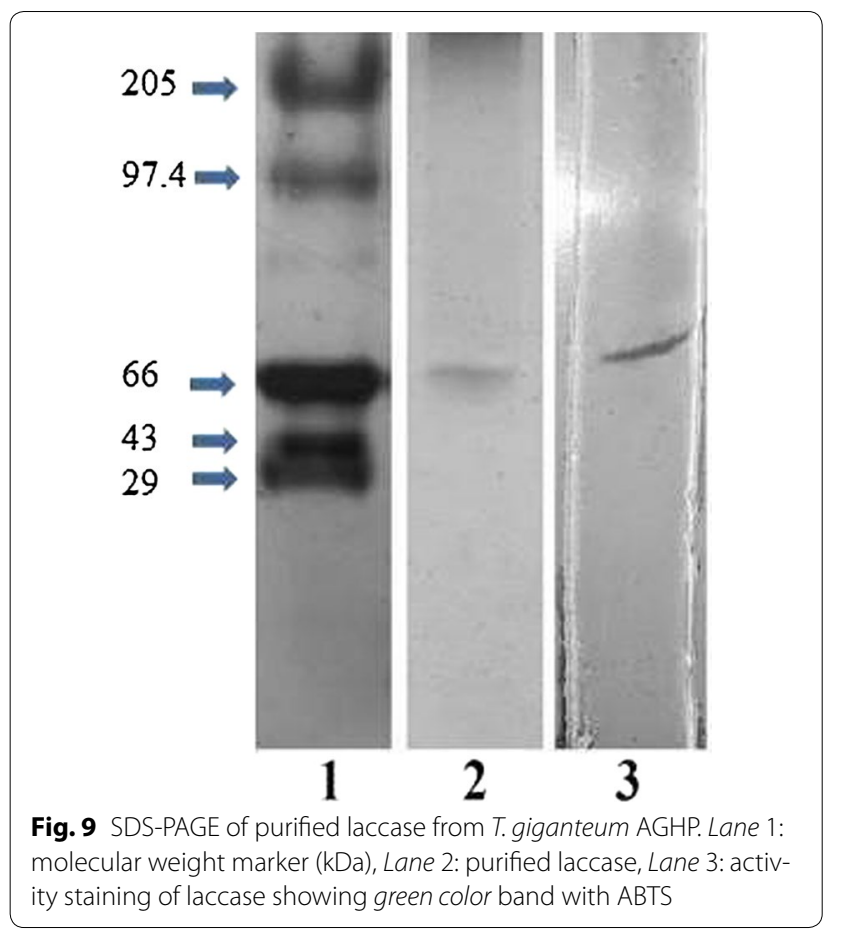

\section{Molecular weight determination}

The purified laccase showed single band on the SDSPAGE, when stained with silver nitrate staining method, indicating the purity of the enzyme sample. The approximate molecular mass of purified laccase was found to be $66 \mathrm{kDa}$ (Fig. 9), which resembles the molecular mass of most fungal laccases (Yang et al. 2013). Native-PAGE using ABTS as a substrate also showed the presence of a single green-colored band, thus suggesting the monomeric nature of the enzyme.

\section{Conclusions}

The present study has revealed the potential of a newly isolated basidiomycete $T$. giganteum AGHP to produce laccase under SSF. The current investigation confirms and evaluates the use of lignocellulosic substrate as an inexpensive and easily available solid substrate for enzyme production. Further, the production of the laccase by this strain can be enhanced by the addition of copper ion as an inducer into the fermentation medium. The overall optimization of all the cultivation conditions using "one-factor-at-a-time" methodology increased the laccase production by 3.02-fold compared to control conditions under SSF using wheat straw as a lignocellulosic substrate. The purified enzyme was recovered with the final yield of $8.50 \%$ with 10.80 -fold purification using DEAE Sephadex A-50 ion exchange chromatography. To the best of our knowledge, this is a first report on laccase production by the fungal strain T. giganteum under SSF. Thus, this isolate can be further explored for the largescale laccase production for its various biotechnological applications.

\section{Authors' contributions}

The study was designed by AG and experimental work was carried out by HP. Both of them contributed equally in the preparation of the manuscript. Both authors read and approved the final manuscript.

\section{Acknowledgements}

The authors are thankful to the Department of Biotechnology (DBT sanction no. BT/PR5859/PID/6/696/2012) and Ministry of Science and Technology, New Delhi, for their financial support. The authors also wish to acknowledge SICART, V.V. Nagar, Gujarat, for providing the necessary instrumentation facilities.

\section{Competing interests}

The authors declare that they have no competing interests.

Received: 24 December 2015 Accepted: 25 February 2016

Published online: 05 March 2016

\section{References}

Arora DS, Gill PK (2000) Laccase production by some white rot fungi under different nutritional conditions. Bioresour Technol 73:283-285. doi:10.1016/ S0960-8524(99)00141-8

Asther M, Lesage L, Drapron R, Corrieu G, Odier E (1988) Phospholipid and fatty acid enhancement of Phanerochaete chrysosporium INA-12 in relation to ligninase production. Appl Microbiol Biotechnol 27:393-398. doi:10.1007/BF00251775

Chaurasia PK, Yadav RSS, Yadava S (2014) Purification and characterization of yellow laccase from Trametes hirsuta MTCC- 1171 and its application in synthesis of aromatic aldehydes. Process Biochem 49:1647-1655. doi:10.1016/j.procbio.2014.06.016

Chhaya U, Gupte A (2013) Effect of different cultivation conditions and inducers on the production of laccase by the litter-dwelling fungal isolates Fusarium incarnatum LD-3 under solid substrate fermentation. Ann Microbiol 63:215-223. doi:10.1007/s13213-012-0464-1 
Chundakkadu K (2005) Solid state fermentation systems - an overview. Crit Rev Biotechnol 25:1-30. doi:10.1080/07388550590925383

Collins PJ, Dobson A (1997) Regulation of laccase gene transcription in Trametes versicolor. Appl Environ Microbiol 63:3444-3450

Couto SR, Osma JF, Toca-Herrera JL (2009) Removal of synthetic dyes by an eco-friendly strategy. Eng Life Sci 9:116-123. doi:10.1002/elsc.200800088

Ding Z, Peng L, Chen Y, Zhang L, Gu Z, Shi G, Zhang K (2012) Production and characterization of thermostable laccase from the mushroom, Ganoderma lucidum, using submerged fermentation. Afr J Microbiol Res 6:1147-1157. doi:10.5897/AJMR11.1257

Dong JL, Zhang YW, Zhang RH, Huang WZ, Zhang YZ (2005) Influence of culture conditions on laccase production and isozyme patterns in the white-rot fungus Trametes gallica. J Basic Microbiol 45:190-198. doi:10.1002/jobm.200410511

Duran N, Rosa MA, D'Annibale A, Gianfreda L (2002) Applications of laccases and tyrosinases (phenoloxidases) immobilized on different supports. Enzyme Microb Tech 31:907-931. doi:10.1016/S0141-0229(02)00214-4

El-Batal Al, ElKenawy NM, Yassin AS, Amin MA (2015) Laccase production by Pleurotus ostreatus and its application in synthesis of gold nanoparticles. Biotechnol Rep 5:31-39. doi:10.1016/j.btre.2014.11.001

Elsayed MA, Hassan MM, Elshafei AM, Haroun BM, Othman AM (2012) Optimization of cultural and nutritional parameters for the production of laccase by Pleurotus ostreatus ARC280. Br Biotechnol J 2:115-132

Giardina P, Faraco V, Pezzella C, Piscitelli A, Vanhulle S, Sannia G (2010) Laccases: a never-ending story. Cell Mol Life Sci 67:369-385. doi:10.1007/ s00018-009-0169-1

Johnsy G, Kaviyarasan V (2011) Effect of nutritional and environmental conditions on production of extracellular laccase under submerged culture conditions in Lentinus kauffmanii. Int J Current Pharm Res 3:105-109

Kapoor M, Beg QK, Bhushan B, Dadhich KS, Hoondal GS (2000) Production and partial purification and characterization of a thermo-alkali stable polygalacturonase from Bacillus sp. MG-cp-2. Process Biochem 36:467-473. doi:10.1016/S0032-9592(00)00238-7

Khan TS, Mubeen U (2012) Wheat straw: a pragmatic overview. Current Res J Biol Sci 4:673-675

Laemmli UK (1970) Cleavage of structural proteins during the assembly of the head of bacteriophage T4. Nature 227:680-685

Lestan D, Lestan M, Perdih A (1994) Physiological aspects of biosynthesis of lignin peroxidases by Phanerochaete chrysosporium. Appl Environ Microbiol 60:606-612

Lowry OH, Rosebrough NJ, Farr AL, Randall RJ (1951) Protein measurements with Folin-phenol reagent. J Biol Chem 193:265-275

Majeau JA, Brar SK, Tyagi RD (2010) Laccases for removal of recalcitrant and emerging pollutants. Bioresour Technol 101:2331-2350. doi:10.1016/j. biortech.2009.10.087

Manavalan T, Manavalan A, Thangavelu KP, Heese K (2013) Characterization of optimized production, purification and application of laccase from Ganoderma lucidum. Biochem Eng J 70:106-114. doi:10.1016/j.bej.2012.10.007

Mann J, Markham JL, Peiris P, Spooner-Hart RN, Holford P, Nair NG (2015) Use of olive mill wastewater as a suitable substrate for the production of laccase by Cerrena consors. Int Biodeter Biodegr 99:138-145. doi:10.1016/j. ibiod.2015.01.010

Mayer AM, Staples RC (2002) Laccase: new functions for an old enzyme. Phytochemistry 60:551-565. doi:10.1016/S0031-9422(02)00171-1

Mendoza L, Jonstrup M, Hatti- Kaul R, Mattiasson B (2011) Azo dye decolorization by a laccase/mediator system in a membrane reactor: enzyme and mediator reusability. Enzyme Microb Tech 49:478-484. doi:10.1016/j. enzmictec.2011.08.006

Niku-Paavola ML, Karhunen E, Kentelinen A, Viikari L, Lundell T, Hatakka A (1990) The effect of culture conditions on the production of lignin modifying enzymes by the white rot fungus Phlebia radiata. J Biotechnol 13:211-221. doi:10.1016/0168-1656(90)90106-L

Palmieri G, Cennamo G, Faraco V, Amoresano A, Sannia G, Giardina P (2003) Atypical laccase isoenzymes from copper supplemented Pleurotus ostreatus cultures. Enzyme Microb Tech 33:220-230. doi:10.1016/ S0141-0229(03)00117-0

Patel H, Gupte A, Gupte S (2009) Effect of different culture conditions and inducers on production of laccase by a basidiomycete fungal isolate Pleurotus ostreatus HP-1 under solid state fermentation. BioResources 4:268-284

Placido J, Capareda S (2015) Ligninolytic enzymes: a biotechnological alternative for bioethanol production. Bioresour Bioprocess 2:1-12. doi:10.1186/ s40643-015-0049-5

Prakasam V, Karthikayani B, Thiribhuvanamala G, Chandrasekar G, Veeralakshmi S, Ahila P, Sakthivel K, Malarkodi B (2011) Tricholoma giganteum-a new tropical edible mushroom for commercial cultivation in India. In: Proceedings of the 7th International Conference on Mushroom Biology and Mushroom Products (ICMBMP7), Convention Centre, Arcachon, France, 4-7 Oct 2011

Ravikumar G, Gomathi D, Kalaiselvi M, Uma C (2012) Production, purification and partial characterization of laccase from the mushroom Hypsizygus ulmarius. Int J Pharm Bio Sci 3:355-365

Revankar MS, Lele SS (2006) Enhanced production of laccase using a new isolate of white rot fungus WR-1. Process Biochem 41:581-588. doi:10.1016/j. procbio.2005.07.019

Rivera-Hoyos CM, Morales-Alvarez ED, Poutou-Pinales RA, Pedroza-Rodriguez AM, Rodriguez-Vazquez R, Delgado-Boada JM (2013) Fungal laccases. Fungal Biol Rev 27:67-82. doi:10.1016/j.fbr.2013.07.001

Sadhasivam S, Savitha S, Swaminathan K, Lin FH (2008) Production, purification and characterization of mid-redox potential laccase from a newly isolated Trichoderma harzianum WL1. Process Biochem 43:736-742. doi:10.1016/j. procbio.2008.02.017

Sakurai T, Kataoka K (2007) Structure and function of type I copper in multicopper oxidases. Cell Mol Life Sci 64:2642-2656. doi:10.1007/ s00018-007-7183-y

Shankar S, Shikha S (2012) Laccase production and enzymatic modification of lignin by a novel Peniophora sp. Appl Biochem Biotechnol 166:10821094. doi:10.1007/s12010-011-9496-4

Sharma KK, Kapoor M, Kuhad RC (2005) In vivo enzymatic digestion, in vitro xylanase digestion, metabolic analogues, surfactants and polyethylene glycol ameliorate laccase production from Ganoderma sp. Kk-02. Lett Appl Microbiol 41:24-31. doi:10.1111/j.1472-765X.2005.01721.x

Songulashvili G, Jimenez-Tobon G, Jaspers C, Penninckx MJ (2011) High production of laccase by Ganoderma lucidum 447 in submerged cultivation on ethanol production residue supplemented with $\mathrm{Cu}^{2+}$. Mycosphere 2:507-513

Strong PJ, Claus H (2011) Laccase: a review of its past and its future in bioremediation. Crit Rev Environ Sci Technol 41:373-434. doi:10.1080/10643380902945706

Thurston CF (1994) The structure and function of fungal laccases. Microbiology 140:19-26. doi:10.1099/13500872-140-1-19

White TJ, Bruns T, Lee SJWT, Taylor JW (1990) Amplification and direct sequencing of fungal ribosomal RNA genes for phylogenetics. In: Innis MA, Gelfand DH, Sninsky JJ, White TJ (eds) PCR protocols: a guide to methods and applications, 1st edn. Academic Press Inc, New York

Xin F, Geng A (2011) Utilization of horticultural waste for laccase production by Trametes versicolor under solid-state fermentation. Appl Biochem Biotechnol 163:235-246. doi:10.1007/s12010-010-9033-x

Yan J, Chen D, Yang E, Niu J, Chen Y, Chagan I (2014) Purification and characterization of a thermotolerant laccase isoform in Trametes trogii strain and its potential in dye decolorization. Int Biodeter Biodegr 93:186-194. doi:10.1016/j.ibiod.2014.06.001

Yang Y, Ding Y, Liao X, Cai Y (2013) Purification and characterization of a new laccase from Shiraia sp.SUPER-H168. Process Biochem 48:351-357. doi:10.1016/j.procbio.2012.12.011 